\title{
Concepts, Strategies and Proposals for the development of Urban Communities"
}

\section{The Anjuman Mimaran Urban Project}

A recent discussion conducted by the Anjuman Mimaran ${ }^{1}$ has generated a concept for urban development that has immediate relevance to Pakistan. It is based on high-density, low-rise, low-tech development that integrates housing employment and social infrastructure, with a balanced mix of income and occupational groups. This concept includes a location strategy that results in

- Affordable housing for all income levels;

- Release of pressure on existing urban centers

- Injection of economic activity into rural areas; and

- Sustainable "green" urban communities;

The following extract from the discussion describes the central argument, supported by a physical layout and analysis of the proposed model.

We would welcome any initiatives to take these proposals further towards practical implementation.

\section{Concept}

There is a huge and growing demand for housing in Pakistan. The natural population increase alone adds more than three million persons a year. Add to this the attrition of existing housing stock, and you have a demand for three good sized cities a year to be accommodated.

The supply side is abysmally low, particularly in the public sector. The performance of the Lahore Development Authority, for instance, over the last decade or so has practically been at a standstill. The gap has been

\footnotetext{
* The paper is a summary of discussions of a seminar on the subject held at The Lahore School of Economics in March, 2000.

1 Discussants: Arif Hassan, Karachi; Ayyub Qutub, Lahore; Tariq Banuri, USA; Dr. Akmal Hussain, Lahore; Babar Khan Mumtaz, London; Tasneem Siddiqui, Karachi; Shahid Khan, Karachi; Raza Ali, Lahore; Nadeem Omar, Lahore; Kamil Khan Mumtaz, Lahore; Masood Ahmad Khan, Lahore; Ayyub Malik, UK.
} 
met by private sector development: authorised schemes in the case of upper and middle-income groups; and mostly un-authorised informal sector development in the case of lower income groups.

Thus in purely market terms, the project is certainly "do-able" and "sellable" as a private venture. As a government policy the model could be adopted at the regional (provincial or national) level as a strategy for the development of new towns, and adapted to the expansion or renewal of existing urban centers.

We contend that the modern city, characterised by function specific land-use zones, segregation of income and occupational groups, high-rise, high tech buildings, dependent on motorised transportation, and sprawling low density suburbs is economically, culturally and environmentally unsustainable. The traditional city, on the other hand, characterised by an integrated community, low-rise, low-tech, high density structures, a network of pedestrian streets, and bounded by a green girdle, provides a more sustainable and appropriate urban mode1.

\section{Integrated community}

- Not a "dormitory" housing scheme but a complete community

- Integrates the whole range of land uses including residential, industry, commerce, services, public administration, social infrastructure, recreation etc.

- Integrates the whole range of income and occupational groups;

Low-rise, low-tech, high density results in

- Smaller urban footprint on the landscape

- Energy conservation and reduced costs of transport and heating/ cooling

- Lower construction costs

- Lower cost of infrastructure

- Human scale built environment

- $\quad$ More green/public open spaces 
Anjuman Mimaran 119

\section{Walkable city provides}

- Safer pedestrian circulation

- Less noise and air pollution

- Encourages social inter-action

- Cu1-de-sacs provide more privacy

Green girdle

- Urban gardens producing fresh fruits and vegetables, dairy and poultry

- Recreational parks for sports and leisure

\section{Strategy}

\section{A. Physical Planning}

The walking city should be limited to not more than one kilometer ${ }^{2}$ across.

A community to which an individual can relate should not be more than 25,000 persons; i.e. the number you can collect in one place and recognise every face ${ }^{3}$.

One advantage of a complete, integrated community, as opposed to the usual "housing" scheme, is that it does not have to be located within the direct catchment area of an existing city. Thus the difference between the cost price of raw agricultural land and marketable price of residential plots can be as high as 1,000 per cent or more. This margin can be used (a) to cover management and professional costs and other overheads; (b) to secure a large green girdle around the proposed urban area; (c) to subsidise utility services and social infrastructure development; or (d) to rake in huge profits.

Physical infrastructure development will be "incremental", keeping pace with the sales of plots and occupation in stages, of kootchas, galis, mohallas and bazaar.

\footnotetext{
${ }^{2}$ May be extended to two kilometers in the case of larger metropolitan centers.

${ }^{3}$ May be extended to 25,000 households in the case of larger metropolis, considering that on average one person per household may be the maximum expected to attend a public gathering. Thus the maximum population may be extended to about 200,000 persons.
} 


\section{B. Building}

Buildings may be constructed by the owners themselves or by the project entity or by other developers, for their own use, for rent or for sale.

Questions of building design, materials and technologies have not yet been addressed by the present discussion. However, it may be presumed that the group will favour strategies based on traditional design typologies, that are appropriate to the local climate and culture, and use indigenous materials and technologies.

\section{Economic Activity}

The key to our whole concept is employment. The following programme should be initiated immediately, and should run as a parallel project to the physical planning and development.

A finance and trade group should be formed to include a bank or other financing institution, and a team of marketing professionals, designers and materials technologies.

Small liaison offices or centers should be established in three or four existing urban centers.

Data should be collected on skills available, and the market demand for products in each existing urban center. This information should be fed into a common data bank accessible to all the centers.

The centers should provide design inputs, technical advice, quality control, marketing services and credit facilities to the individual artisans and small-scale producers.

As and when the physical development of our new community comes on stream, the centers should become our marketing points to "sell" the new town to prospective residents, workers and employers etc.

The new town will offer opportunities for a range of economic activities: (a) urban farming, dairy, poultry, orchards, forestry, country club and sports activities in the green girdle. (b) Small scale, manufacturing and home based industries and workshops. (c) Retail and wholesale commercial activities. (d) Urban management and utility services. (e) Construction. (f) Transport. (g) Service industries. (h) Social infrastructure services. (i) Performing and visual arts. (j) Professional services etc. 
The green girdle land will be owned by the "project" and leased or rented to urban farmers and other users.

Finance to manufacturing and business enterprises and building finance will be provided by the centers in some form of equity participation.

\section{Proposal}

In the following iteration of our urban project, with a rough working sketch-plan (see attached), we have used the Govt. of Pakistan, Ministry of Housing's "National Reference Manual on Planning and Infrastructure Standards” (NRM) as our reference for plot sizes, occupancy, land use, density and affordability. The tabulated analysis is attached.

\section{Composition of Plots}

Our largest plots, 312 to 500 sq. meters, form 3 per cent of the total number of plots compared with 5 per cent in the NRM. Our medium sized plots, 160 to 250 sq. meters, form 8 per cent of the total compared with 20 per cent in NRM. Our smallest plots, 72 to 105 sq. meters, form 89 per cent of the total compared with 75 per cent in NRM.

\section{Dwelling Units}

NRM gives average household sizes ranging from 5 to 8 persons in upper income communities and 6 to 10 in low-income communities. We have taken household sizes of 8 and occupancy of 1.5 households per dwelling unit. Thus for an ultimate population of 25,000 the number of dwelling units would be about 2,083 .

\section{Land Use}

Our allocation for residential land use, 65.48 per cent, is much higher than the NRM standard of 45 to 52 per cent. This is a direct consequence of our use of narrow pedestrian streets, which take up less than 12 per cent of the land compared with 25 to 30 per cent in NRM.

Our allocation for open public spaces within the built up area, 1.91 per cent, appears less than the NRM standards of 5 to 7.5 per cent. But this is more than compensated for by the provision of the very large green girdle which will include public open spaces in addition to urban gardens and other green uses. 
We have a larger percentage of land allocated for "other" uses, 8.73 per cent, compared with 2 to 5 per cent in NRM. This may be used for a variety of possible employment generating activities.

\section{Density}

NRM gives a range of residential densities in which the highest is 690 persons per hectare in zones comprising "mainly small plots". With our ultimate population of 25,000 and our built-up urban area of 33.5 hectares we will have a density of 746.27 persons per hectare.

\section{Financial Analysis}

On the expenditures side we have allowed for a basic cost of land at Rs. 125,000 per acre $^{4}$, Professional services at Rs. 100,000 per acre; infrastructure development at Rs. 500,000 per acre; Administrative overheads at 10 per cent of project cost; and money cost at 15 per cent of capital investments. Thus the total project cost would be Rs. 93.46 million, or less than two million dollars.

On the revenue side we have taken sale of plots and development charges based on the current prices of the lowest cost housing schemes available in the peripheral areas of Lahore. At these prices we should be able to recover all our costs and end up with an asset in terms of some 60 hectares of agricultural land and a fully developed infrastructure of utility services. These can yield continuing annual revenue for the city in terms of land rents, leases and utility charges.

\section{Affordability}

We have checked the affordability of each category of residential plot against the household incomes, using the NRM standard of 3.5 times

\footnotetext{
${ }^{4}$ One community based organisation has recently provided residential plots of $62.7 \mathrm{sq} . \mathrm{m}$ (3 marlas), in a peripheral area near Lahore, at the rate of Rs. 18,000 per plot. To this is to be added another Rs. 7,000 for physical infrastructure services and other costs. At this rate the basic cost of the average plot of 105.6 sq.m. in our project would be Rs. 30,316 without infrastructure development, and Rs. 42,105 for a serviced plot. In another subsidised government scheme for low income housing comparable plots are being sold (illegally) for Rs. 100,000 and more. In private sector developments similar plots can fetch up to Rs. 500,00.

At the lowest price quoted above, the cost of land works out at Rs. 2,323,680 per hectare, or Rs. 801,269 per acre. This is within the range of agricultural land prices in some peripheral areas around Lahore, e.g. off Bedian Road. Beyond the sphere of influence of the major cities agricultural land prices are naturally much lower, Rs. 100,000 per acre in Kallar Kahar, and even less in the border areas towards Kasur.
} 
the annual income of the household. We have assumed a building area equal to the NRM recommended maximum ground coverage for various plot sizes, and minimum building costs compatible with each income group. Thus a house of 573 sq. feet (53 sq. meters) on a plot of 3.4 marlas ( 72 sq. meters) in our scheme would cost Rs. $210,000(\$ 4286)$ and would be affordable by a family with an income of Rs. 5,000 (\$102) per month ${ }^{5}$. Similarly, a house of 2,183 sq. feet (203 sq. meters) on a plot of 15 marlas (313 sq. meters) would cost Rs. 1,211,499 (\$24724) and would be affordable by a family earning Rs. 30,000 (\$612) per month.

\section{Analysis Tables}

Sheet-1: $\quad$ Composition of Plots

Dwelling Units

Land Use

Density

Sheet-2: $\quad$ Financial Analysis

Sheet-3: $\quad$ Affordability

\footnotetext{
${ }^{5}$ A serviced plot with a very basic shelter will be affordable by still lower income groups - see Category "F" (1).
} 
Sheet-1

\section{Composition of Plots}

\begin{tabular}{|c|c|c|c|c|}
\hline Category & $\begin{array}{c}\text { Plot Area } \\
\text { Sq. M } \\
\end{array}$ & $\begin{array}{l}\text { Allocation } \\
\text { Percentage } \\
\end{array}$ & $\begin{array}{c}\text { Total Area } \\
\text { Sq. M } \\
\end{array}$ & $\begin{array}{c}\text { NRM } \\
\text { Percentage }\end{array}$ \\
\hline A & 500.00 & 0.00 & 0.00 & 5.00 \\
\hline A1 & 420.00 & 1.00 & 420.00 & \\
\hline B & 312.00 & 2.00 & 624.00 & \\
\hline $\mathrm{C}$ & 250.00 & 2.00 & 500.00 & 20.00 \\
\hline $\mathrm{D}$ & 160.00 & 6.00 & 960.00 & \\
\hline $\mathrm{E}$ & 105.00 & 49.00 & 5145.00 & 75.00 \\
\hline $\mathrm{F}$ & 72.00 & 40.00 & 2880.00 & \\
\hline Total & & 100.00 & 10529.00 & \\
\hline Average & 105.29 & & & \\
\hline Dwelling Units & & & & \\
\hline Population & 25000.00 & & & \\
\hline Occupancy & 12.00 & \multicolumn{2}{|c|}{ persons per DU } & \\
\hline Number of DUs & 2083.33 & & & \\
\hline Res. Area & 21.94 & Hectares & & \\
\hline \multicolumn{5}{|l|}{ Land Use } \\
\hline Category & $\begin{array}{c}\text { Area } \\
\text { Hectars }\end{array}$ & $\begin{array}{c}\text { Allocation } \\
\text { Percent }\end{array}$ & & $\begin{array}{c}\text { NRM } \\
\text { Percentage }\end{array}$ \\
\hline Residential & 21.94 & 65.48 & & $45-52$ \\
\hline Commerce & 1.00 & 2.99 & & $2-3$ \\
\hline Edu. \& Com. & 3.00 & 8.96 & & $7.5-10$ \\
\hline Streets & 4.00 & 11.94 & & $25-30$ \\
\hline Open & 0.64 & 1.91 & & $5-7.5$ \\
\hline Others & 2.92 & 8.73 & & $2-5$ \\
\hline Total & 33.50 & 100.00 & & \\
\hline Density & 746.27 & \multicolumn{2}{|c|}{ Persons per hectare } & \\
\hline
\end{tabular}


Sheet-2

\section{Financial Analysis}

\begin{tabular}{|c|c|c|c|c|c|}
\hline Expenditures & Quantity & Unit & $\begin{array}{c}\text { Rate } \\
\text { Pak. Rs. }\end{array}$ & $\begin{array}{l}\text { Amount } \\
\text { Mil. Rs. }\end{array}$ & $\begin{array}{c}\text { US\$ @ } \\
\text { 49.00 Pak. } \\
\text { Rs. } \\
\end{array}$ \\
\hline $\begin{array}{l}\text { Land for } \\
\text { urban dev. }\end{array}$ & 30 & Hectares & 362500 & 10.88 & 221938.78 \\
\hline $\begin{array}{l}\text { Land for } \\
\text { green belt }\end{array}$ & 60 & Hectares & 362500 & 21.75 & 443877.55 \\
\hline $\begin{array}{l}\text { Professional } \\
\text { services }\end{array}$ & 30 & Hectares & 290000 & 8.70 & 177551.02 \\
\hline $\begin{array}{l}\text { Infrastructure } \\
\text { development }\end{array}$ & 30 & Hectares & 1450000 & 43.50 & 887755.10 \\
\hline $\begin{array}{l}\text { Admin. } \\
\text { Overheads }\end{array}$ & 84825000 & Rupees & $10 \%$ & 8.48 & 173112.24 \\
\hline Money cost & 1015000 & Rupees & $15 \%$ & 0.15 & 3107.14 \\
\hline Total Cost & & & & 93.46 & 1907341.84 \\
\hline $\begin{array}{l}\text { Number of } \\
\text { Plots }\end{array}$ & 30 & Hectares & 75 & 2250.00 & \\
\hline $\begin{array}{l}\text { Cost/plot marla } \\
\text { (20.89sq.m) }\end{array}$ & & & 8034 & 0.00 & \\
\hline \multicolumn{6}{|l|}{ Revenue } \\
\hline Sale of plots & 2250 & Plots & 31020 & 69.80 & 1424387.76 \\
\hline $\begin{array}{l}\text { Development } \\
\text { charge }\end{array}$ & 2250 & Plots & 12063 & 27.14 & 553913.27 \\
\hline Total & & & & 96.94 & 1978301.02 \\
\hline \multicolumn{6}{|l|}{$\begin{array}{l}\text { Annual } \\
\text { Revenue }\end{array}$} \\
\hline Green belt & 70 & Hectares & 34800 & 2.44 & 49714.29 \\
\hline Utility Services & 2472 & Plots & 1000.00 & 2.47 & 50448.98 \\
\hline Total & & & & 4.91 & 100163.27 \\
\hline
\end{tabular}


126 The Lahore Journal of Economics, Vol.6, No.2

Sheet-3

\section{Affordability}

\begin{tabular}{|c|c|c|c|c|}
\hline Category “F” & Quantity & Unit & $\begin{array}{c}\text { Rate } \\
\text { Pak. Rs. }\end{array}$ & $\begin{array}{l}\text { Amount } \\
\text { Pak. Rs. }\end{array}$ \\
\hline Income & 12 & Months & 5000 & 60000.00 \\
\hline Building & 573.75 & sft. & 325 & 186468.80 \\
\hline Land \& development & 3.4 & Marlas( 21s.m.) & 8034 & 27316.84 \\
\hline Total & & & & 210000.00 \\
\hline $\begin{array}{l}\text { Affordable @ NRM Std. } \\
\text { Category"F"(1) }\end{array}$ & 60000 & Rs./year & 3.5 & 210000 \\
\hline Income & 12 & Months & 2000 & 24000.00 \\
\hline Building & 250 & sft. & 225 & 56250.00 \\
\hline Land \& development & 3.4 & Marlas( 21s.m.) & 8034 & 27316.84 \\
\hline Total & & & & 83566.00 \\
\hline $\begin{array}{l}\text { Affordable @ NRM Std. } \\
\text { Category "E" }\end{array}$ & 24000 & Rs./year & 3.5 & 84000.00 \\
\hline Income & 12 & Months & 8000 & 96000.00 \\
\hline Building & 872.4375 & sft. & 340 & 296628.80 \\
\hline Land \& development & 5.17 & Marlas( 21s.m.) & 8034 & 41537.67 \\
\hline Total & & & & 338166.40 \\
\hline $\begin{array}{l}\text { Affordable @ NRM Std. } \\
\text { Category “D” }\end{array}$ & 96000 & Rs./year & 3.5 & 336000.00 \\
\hline Income & 12 & Months & 11000 & 132000.00 \\
\hline Building & 1206.45 & sft. & 340 & 410193.00 \\
\hline Land \& development & 7.66 & Marlas( 21s.m.) & 8034 & 61543.24 \\
\hline Total & & & & 471736.20 \\
\hline $\begin{array}{l}\text { Affordable @ NRM Std. } \\
\text { Category "C" }\end{array}$ & 132000 & Rs./year & 3.5 & 462000.00 \\
\hline Income & 12 & Months & 19000 & 228000.00 \\
\hline Building & 1749.306 & sft. & 400 & 699722.50 \\
\hline Land \& development & 11.96107 & Marlas( 21s.m.) & 8034 & 96099.58 \\
\hline Total & & & & 795822 \\
\hline $\begin{array}{l}\text { Affordable @ NRM Std. } \\
\text { Category “B” }\end{array}$ & 228000 & Rs./year & 3.5 & 798000.00 \\
\hline Income & 12 & Months & 30000 & 360000.00 \\
\hline Building & 2183.134 & sft. & 500 & 1091567.00 \\
\hline Land \& development & 14.92741 & Marlas( 21s.m.) & 8034 & 119932.30 \\
\hline Total & & & & 1211499.00 \\
\hline Affordable @ NRM Std. & 360000 & Rs./year & 3.5 & 1260000.00 \\
\hline
\end{tabular}


Anjuman Mimaran 127

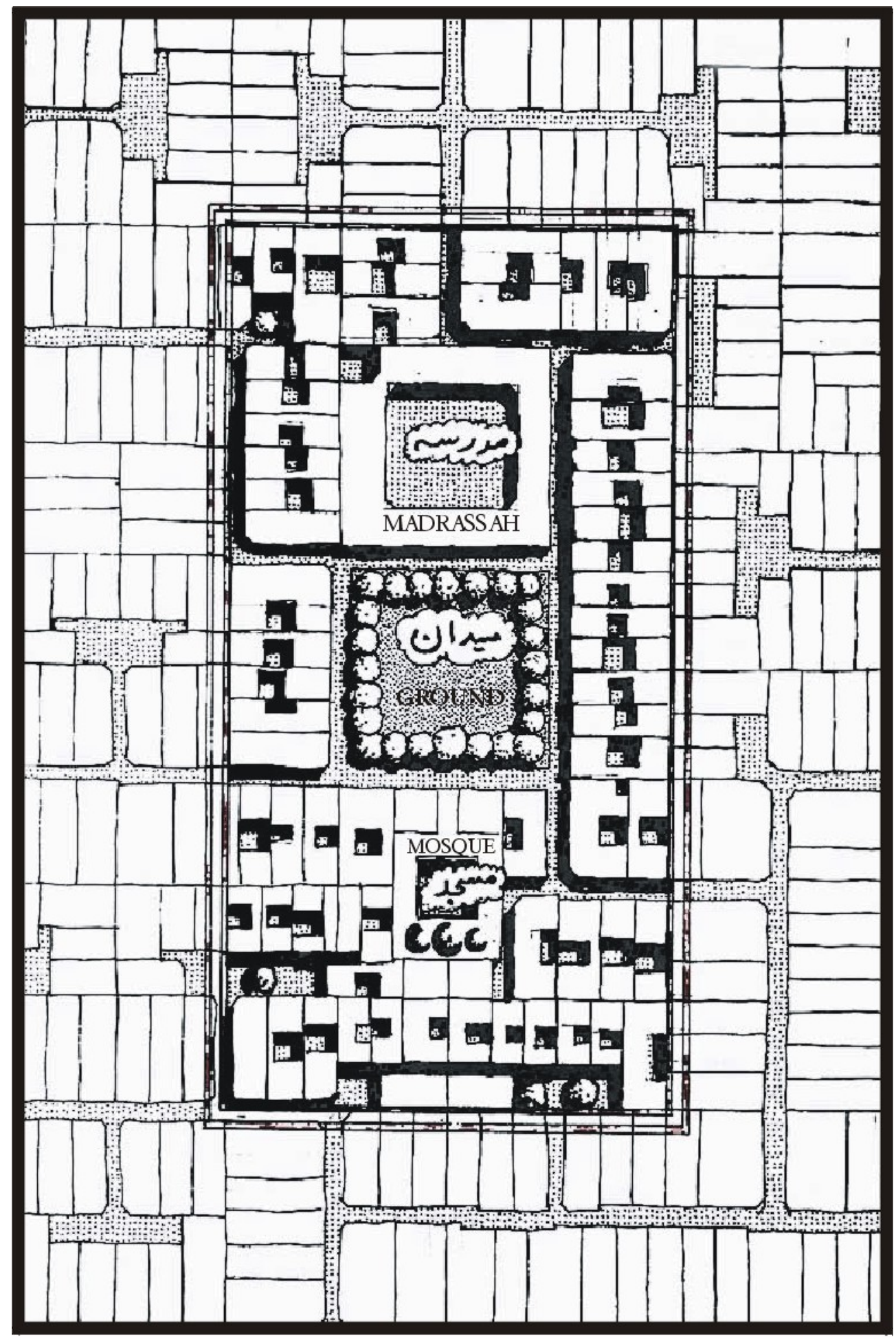

Scale: $1 \mathrm{~cm}=7.82 \mathrm{~m}$ 
128 The Lahore Journal of Economics, Vol.6, No.2

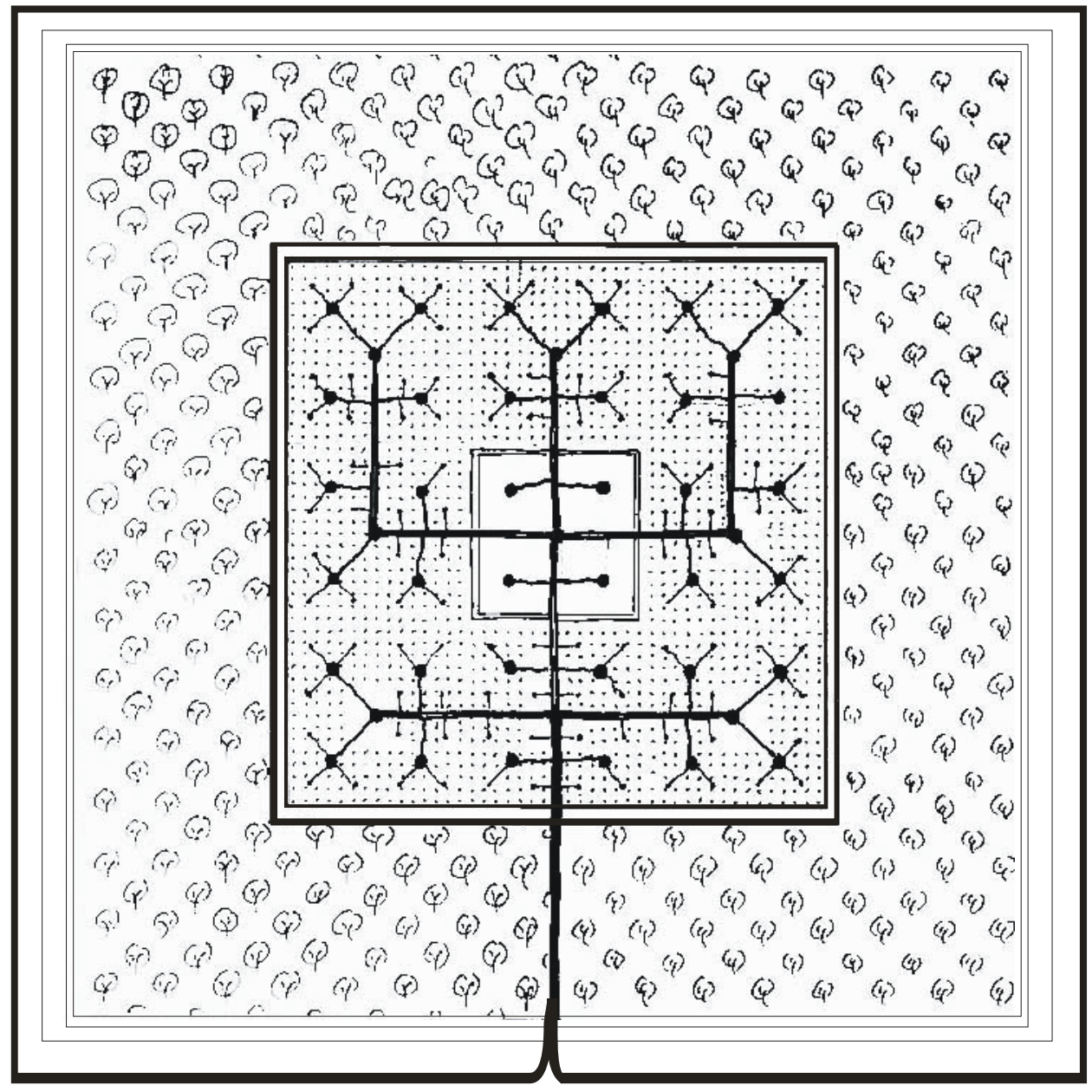

Scale: $1 \mathrm{~cm}=290 \mathrm{~m}$

City Population: 2 Lakh 


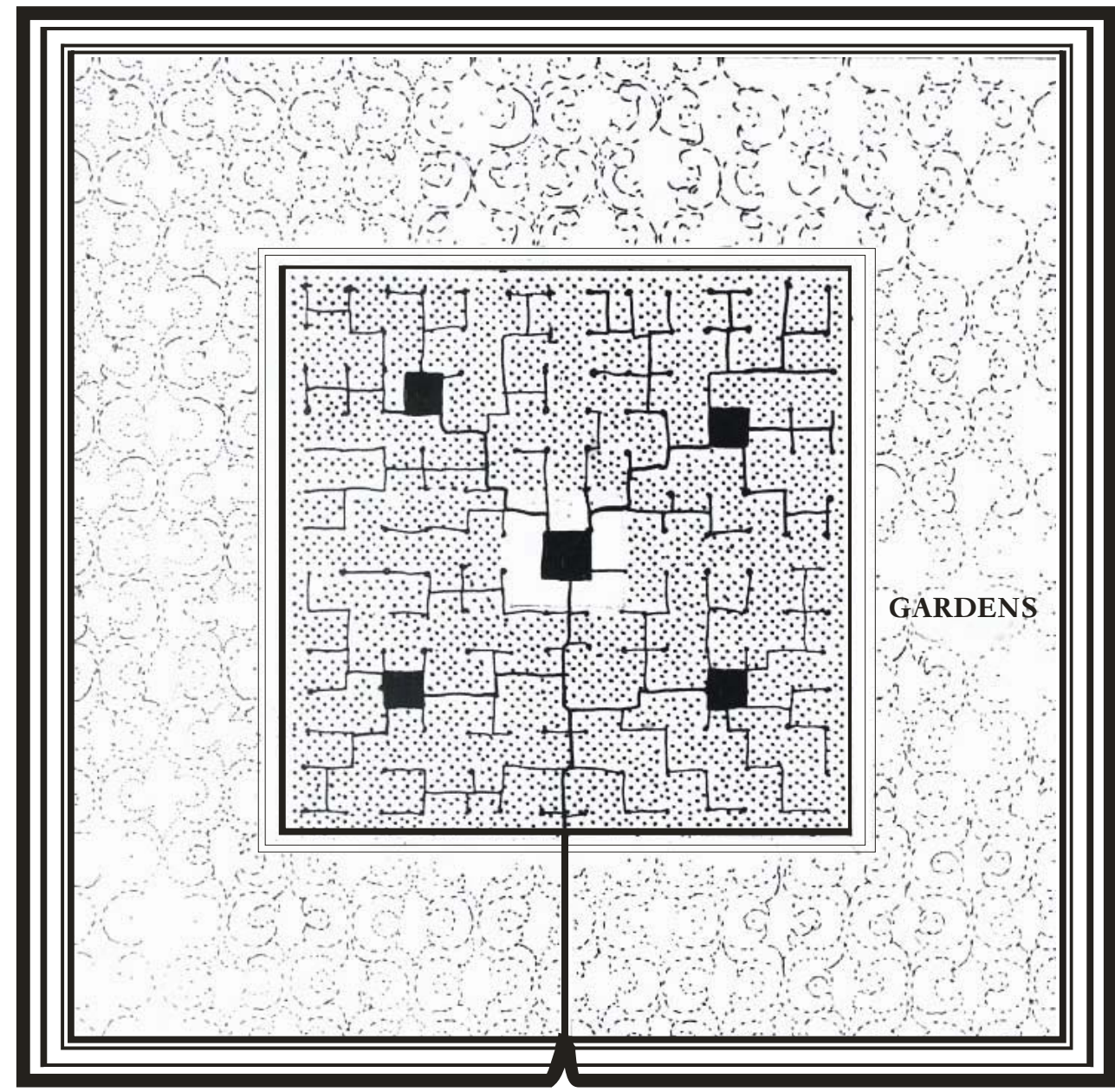

Scale: $1 \mathrm{~cm}=144 \mathrm{~m}$

Town Population: 2000 